\title{
Prophetic Bases of Islamic Moderation of State Islamic Higher Education (PTKIN)
}

\author{
Moh. Sulhan \\ Islamic Education Management Department \\ UIN Sunan Gunung Djati \\ Bandung, Indonesia \\ muhsulhan@uinsgd.ac.id
}

\author{
Hasbiyallah Hasbiyallah and Dadan Nurul Haq \\ Islamic Education Department \\ UIN Sunan Gunung Djati \\ Bandung, Indonesia \\ hasbiyallah@uinsgd.ac.id
}

\begin{abstract}
One of the elements of Indonesian Islam that plays a strategic role in developing Islam Indonesia rahmatan lil 'alamin is the State Islamic Higher Education or PTKIN. The dynamics of Islam in Indonesia increasingly reveals in the era of the 1960s and decades of the 70s when institutionally the Ministry of Religious Affairs of the Republic of Indonesia released PTKIN with the form of the Institute that developed the discipline of religious Knowledge in the form of various Faculties. From here later also developed variants of the state Islamic Higher School and then State Islamic University with the development of study areas outside the religious discipline. The existence of PTKIN is important to be observed amid the dynamics of social challenge and the issue of rapid social change. One of them is related to the rise of violence, communal conflict and religious radicalism. The fundamental problem that focuses on this paper is related to how Islamic Higher Education [PTKIN] plays importance role in the context of the dynamics change, how to face the violence and religious fundamentalism today, and what is the root of violence and religious conflict. Hereinafter review the significance of the presence of PTKIN and the prophetic source of Islamic moderation of PTKIN. The universalism and openness of the Islamic treasury of PTKIN become the main reference of an open, dynamic and tolerant Islam. Islam developed in PTKIN became a mecca of Islamic development in Indonesia. To this day PTKIN remains one of the most strategic and systematic cultural Institution in developing Islam rahmatan lil alamin. Place a nursery of values and build an open religious outlook and appreciate the differences.
\end{abstract}

Keywords-Islam; PTKIN; Moderation; Communal Conflict component; formatting

\section{INTRODUCTION}

Islam is a living social phenomenon, an important subject study that owesomes an academic attraction. Especially when religion deals with social change and the actual problems that Islam has to answer [1] [2] [3] [4] [5] [6] [7]. Islam as a religion has actually been the target of study not only by Muslims but also by non Muslims for various purposes and interests with various approaches [8]. The Indonesian Islamic Studies conducted by Dutch scholars and orientalists is widely intended for political and policy purposes concerning the fate of Muslim-majority earthlings [9].
Islamization or Islamic study in Indonesia is a product of increasing Islamic awareness among the people of Indonesia and major changes among scholars who define themselves as Islamists [4]. In the last decade, however, Indonesian Islamic studies have been mentioned by Jhon Esposito [10] too elitist. Islamic studies are a conservative and philologically oriented discipline. Even in some traditional Islamists it is seen that the publication of a critical edition of a classical text is superior in value to a translation or thematic analysis. Mark R. [4] also critically argues that critical study does play an important role in text-oriented scholarship, but the texts themselves are published in fragments that are hard to read and fill with insertions, and often not reaching a wider audience. This conservatism of Islamic studies is entirely philological, combined with Arab or Persian centrism, clearly has contributed to what Jhon Bowen [11] said as conservatism.

Starting from the above conditions, the study of Islamic Studies has undergone a fundamental change over the past two decades. The following books published such as Islam Fundamental [12], Islam Rasional, Islam Realitas [3], Islam Aktual [1], is an effort to answer the challenges of social change. Islam in today's context must widen the study and extend its attention to the actual problem, the reality that Islam needs to answer. The issue of violence in the name of religion, suspicious inter-religious relationships, democracy, human rights, and women is a religious issue that should be paid attention by Islam as a religion of rahmatan lil alamin. Widespread violence in the name of religion and violence that shook the region and the Islamic world also gave rise to attention. The book of Islam Radikal [13], is the construction of how the root causes, problems and answers of Islam over conflicts lead to religion and religious sentiments. The emancipatory study and the imperative of Islamic involvement over the Praxis of liberation can be seen from the work of progressive youth Very Verdiansyah in Islam Emansipatoris [14]. Similar responses to violence and religious conflicts that bring huge casualties are then the concern of major Islamic thinkers and scholars. See for example, Islam Tanpa Kekerasan [15], Traditionalisme Radikal [16] which further illustrates the dynamics and creativity of Islamic studies in responding to the dynamics of the ummah and social change today. 
Hasan Hanafi may have a point [17] [18] [19]. As modernization so rapidly enters all the niches of the life of the third world, it is then that they are again looking for the identity of their self, their nationality, and even their religious identity. It is as if he were saying that a line of Western- life style that is transmitted through various media has dumped the authentic identity and therefore the original identity must be recaptured. In Indonesia the form of fighting for the identity of Islam is done in many ways. One of the efforts of how to fight for Islam is through the cultural path [20] [21] by making Muslims as strong civil society and able to do bargaining position with various interest groups and power to be a smart and empowered community. The other side chooses the structural path [22] by winning power by sticking to the principle of religion. Islamic studies increasingly strengthened with a varied form. Contesting the identity of Islam, one side rejects all traditions outside Islam [22], the other side is the progressively re-actualization of tradition [23] and even sees creatively Islam dialogues with local culture. Claiming claims of Islamic truth also evolved varied, emerged how to return to the Islamic source of the Qur'an and Hadith as they introduced and fight for such as Islamic Fundamentalism. Using western rationalism and humanism is also used for the re-actualization of Islam as a religion that must be in accordance with its time, this is the path of later Islamic struggle as Rational Islam, or Liberal Islam. Later also appear to be a strong response and efforts to change the social order in a more extreme way that is Radical Islam [3]. In another dynamic the author gives another term that essentially is a religious spirit, born to how to dialogue Islam so that it has relevance to today's demands. Although there is a path that chooses the traditional way, using the heart and some who choose the way rational or modern and even those who look all relative as it is understood by postmodern Islam [23] [24].

Cassirer [25] calls humans are living in a symbolic universe. Language, myth, art and religion are part of the universe, all these are yarn threads that form a symbolic web, a tangled web of human experience. All human progress in thinking and experience refines and strengthens this network to understand the shape of human culture. Religion will bear symbolic creation or symbolicum animal. Religion understood by Cliffort Geertz [3] is not an autonomous entity, but it is tied to the context, circumstances and times that surround it. Islam always performs socio-cultural direction in which Islam is located. Therefore Islam will display a variety of faces that are often different. Islam must be kept alive, read and interpreted according to its socio-cultural context to find its ideal form. It is undeniable that this dialogue and encounter will give rise to combat, negotiation and accommodation forming different religious traditions and traditions of religion. This is a rich Indonesian Islam face and an important phenomenon for the study of human life [17].

Amid the dynamics of socialization and the issue of rapid social change. Violence, communal conflict and religious radicalism emerge as a frightening global threat. Massively attacks radical group to innocents victims and causing heavy casualties, is a patterned phenomenon due to a biased religious understanding [26]. The emergence of ISIS in Syria and Iraq, Boko Haram Nigeria and Alqaeda Yemen, al
Sahab Somalia has carried out 664 attacks with 5042 victims (BBC 2014). In some degree it will also be a new threat in Indonesia.

\section{PTKIN AND THE CHALLENGE OF RADICALISM}

Entering the 1960s and the edge of 1970s, the dynamics of Islamic studies more festive when the Ministry of Religious Affairs of the Republic of Indonesia promotes with High Religious Education. Untill this day in Indonesia the study of Islam continues to wriggle. Researchers can not ignore the existence of PTKIN which continues to become an Islamic institution that studies and as locomotives of Islamic studies in Indonesia. Currently there are state Islamic colleges [PTKIN] in Indonesia under the auspices of the Ministry of Religious Affairs of the Republic of Indonesia, in the form of university [UIN], institute [IAIN] and high school [STAIN]. Today's data is encouraging that there are 53 PTKINs consisting of 11 UINs, 23 IAINs, and 19 STAINs scattered throughout Indonesia [Wikipedia.Org]. The State Islamic University began to develop interdisciplinary studies, not just the Islamic studies which are being studied academically at this institution but have begun to develop themselves into non religion areas of studies such in area of humanities and science. For example in UIN Alauddin Makasar, UIN Ar Raniri Banda Aceh, UIN Maulana Malik Ibrahim Malang, UIN Sunan Gunung Djati Bandung, UIN Sunan Kali Jaga Jogyakarta, UIN Syarif Hidayatullah Jakarta, UIN Raden Fatah Palembang, UIN Sultan Syarif Kasim Pekan Baru, UIN Sumatera Utara Medan, UIN Sunan Ampel Surabaya, and UIN Walisongo Semarang. Islamic studies are not only carried out at the undergraduate and even postgraduate level, especially the Master and Doctoral programs. Similar things are also seen in the IAIN Cirebon, IAIN Serang, IAIN Tulungagung, IAIN Surakarta and also STAIN Pekalongan and other.

The stretch of Islamic studies also moves on, develops creatively and dynamically. Interesting to be observed later, in this PTKIN dynamics, in addition to institute, then developed also variants of Islamic High School and then State Islamic University with the development of study areas outside the religious family.

Amid the emergence of religious violence and terrorism in the name of religion, the presence of PTKIN has an important role in answering this crucial problem. Especially, when religion is supposed to be a tool for building inner welfare, spiritual coolness and social adhesion are transformed into conflict triggers. Religion is a source of violence in various regions. Religion appears in a scary face, a source of legitimacy of violence. Religious violence in Indonesia is big irony. Cases that occurred in Poso, Papua, Kalimantan, Sulawesi, Ambon, Maluku, Tasik, Madura, Cirebon and Kuningan, some cases of religious group conflict. As a result of religious contact and socio-cultural dynamics, it is often overlooked by rising demands. As a result the vital role of religion is often eliminated in human life. Religion experiences desacralizing, losing its transcendental spirit. Violent conflict in Indonesia resulted in the death of 10,758 people from 19902003. (UNDP-Bappenas, 2005). The largest proportion of ethno-communal conflicts (between ethnic, religious and religious sects) amounted to 89.3 percent and swallowed 9,612 
victims. Conflict occurred in 14 provinces where the highest case occurred in North Maluku (72 incidents and 2,794 casualties); Maluku (332 incidents and 2,046 fatalities) and West Kalimantan (78 incidents and 1,515 fatalities). The price is too expensive. Too many victims of vain life. Therefore a strategic effort to reduce religious violence must be done. If it is allowed to go on, it will harm all parties. Special Indonesia as a great nation, which is multi ethnic, sect and religion. PTKIN as one of the pillars of Indonesian Islam is also required to have attention related issues such as this. Therefore it is important to look at the prophetic foundation that became the foundation of Islamic moderation of religion of PTKIN in Indonesia

\section{RoOTS OF RELIGIOUS VIOLENCE AND RADICALISM}

Violence on religious grounds is contrary to the religious nature that carries the mission of salvation. Religion, which should be universal values as the basis for the basic principle of life, is not fully understood. Religion is still read unilaterally, which gives birth to an exclusive outlook, excessive fanaticism that tends to be discriminatory. Religion in this position tends to be politicized, manipulated, thus losing the principle of respect for humanity, mercy, wisdom and anti-difference. Though the difference is the main gate to complement each other, fill each other, learn from each other, so that humankind has dignity, glory and increase the subjectivity of self in association with others [27].

The issue of religious radicalism, covering a fairly complex problem. Because it involves the dimension of life, such as beliefs, interpretation of texts, teachings, personal relationships and society. Religious radicalism is thought to have a close connection with religious mythology, the problem of interpretation and symbolic diversity, the problem of injustice and global political problems, the inequality of values and inequality, the problem of nationality and the issue of modernity [3] [26]. Other writer Moh. Nurul Huda, in "Religious Radicalism and Nationality Problem" mentions that radicalism is also related to the level of education, social environment, tradition, culture, willingness, and understanding of every change. In other words the issue of religious radicalism will be vertical and horizontal.

Komarudin Hidayat [28], sees a close relationship between religious radicalism and the problem of religious mythology. The way in which metaphysical thinking tends to be antihistorical, and anti-modern civilization. Reality is considered pseudo, virtual, and imperfect. Religious mythology can give birth to a radical attitude that appears in two paradoxical forms. First, escapist radicalism, seeking to give up worldly life, to a life of asceticism, to free oneself from worldly pleasures that are considered toxic and cyber. Second, theological-ideological radicalism, building an exclusive community, as a container of the identity of the group vis a vis the surrounding world that is considered decadent, like a demonic world that must be eradicated. This second group believes that he is most righteous, closest to God. Fighting against unbelievers is virtue, while death is taking off to God's primordial home. For them life is the way to God, and death is the gateway of everlasting life. It is this ideological-theological attitude that can create social, political and humanitarian disasters, which will cause religious slander.

The activities carried out by radical religious groups realistically often cause tension in people's lives. Radical names in various religious groups, usually associated with the activities undertaken, planned goals, basic and philosophy adopted. Radical nicknames are usually given to denominational groups who fight for religious principlesfundamentally, in a rigorous, firm and strictly uncompromising manner. This, causing religious radicalism is often also referred to as fundamental, extreme or militant terms. If the coincidence of violence or radicalism is done Muslims can be called with radical Islam or fundamental Islam.

As a result of radical religious group activity, it often generates community tension and anxiety. As a result of this tension, the negative impression of the people of this religious movement has arisen. Mochtar Buchori [29] reveals that Radical justification, often raised by the public, is because they are generally intolerant, intolerant fundamentalists, intolerant extremists and intolerant militants. Zainudin Fananie in Islam Radikal dan Perubahan Sosial [13] at least sees two arguments for why religious radicalism has tension in society. First, their intolerance and attitude toward different views, attitudes, and behaviors. This intolerance attitude is usually visualized in the form of protests, or demonstrations. But did not rule out the visualization will turn into a riot mass. Secondly, the existence of a radical religious group that has a habit of forming special sections within the body of their organization-which in its further development grows into a military movement.

Abu Hafsin [30] Described, Internal or inter-religious conflicts are likely to continue, for several reasons. First, the strengthening of fundamentalism, radicalism and even terrorism in the country. Secondly, the maturity of the community is not optimally coupled with the low participation of the community in creating internal harmony and interreligious community. Third, the absence of organic law that serves as the implementation of Article 29 of the Constitution of the Republic of Indonesia. Fourth, the greed of government officials in upholding the law in the community in case of religious conflict.

These religious phenomena and conflicts in the future will continue to escalate. The main factors concerning mission, maturity and readiness to see different religions. According to Fadlolan Musyaffa [30], the tension that often arises within the intra or inter-religious community is due to the following: first, the nature of each religion containing missionary or missionary tasks; secondly, the lack of knowledge of the believers of their own religion and of other religions. Its religion is more dominated by the attitude of fanaticism and narrowness (taklid buta); thirdly, religious adherents are incapable of restraint, so lack of respect and even despise of other religions; fourth, the blurring of the boundaries between attitudes of religious belief and tolerance in social life; fifth, suspicion of each will the honesty of other parties, both internal religious and interreligious; sixth, lack of mutual understanding in facing the problem of dissenting opinion 


\section{MODERATION BASES OF PTKIN}

If examined more closely the basic Islamic moderation of PTKIN boils down to the understanding of Islamic law that is more oriented to the maslahah. Therefore Islam in PTKIN always inclines on the understanding of religion that leads to kemaslahatan and kerahmatan. Abu-Nimer, asserted that "Islam is a living religion and tradition that promotes peacebuilding and the non-violent settlement of conflicts" [31]. Some of PTKIN's prophetic moderate foundations are viewed from the following religious point of view:

\section{A. Choosing the Way of Peace}

Islam is a religion of peace. Islam teaches its people to love peace and away from enmity. If two groups are at war then the command in the Qur'an is reconciled from both. If the enemy is also inclined towards peace then the Qur'anic command is advocated in the way of salvation and peace. In Sura 8:61 "And if they incline toward peace, then lean unto him and strive Allah unto God. He is the Hearer, the Knower. And it is also written from the other epistle, 49: 9, "And if there are two classes of believers fighting then reconcile between the two. If one of the two groups is persecuting another, then fight the group that commits the persecution so that it returns to God's command; if the party has returned (to the command of Allah), then reconcile between the two of them justly and act justly. Allah loves those who are just. This verse expressly calls on Muslims to choose the path of peace. Muslims are brothers. And reconcile if there is hostility. In Sura 49:10 "Surely the Believers are brothers therefore reconcile between your two brothers and fear Allah to have mercy

\section{B. Diversity is Human Fitrah}

Man was created by God in different colors and languages. Humans are creatures who are naturally diverse in both sexes, ethnicities and religions. Sura 49:13 "O mankind, We created you from a man and a woman, and made you nation and tribe so that you may know one another. Verily the most honorable among you in the sight of Allah is the most wicked among you. Allah is Knower. This is God's will to be a lesson for humans. So that people can learn from each other, develop themselves and know. It is easy for God if he wants to make a man of uniform. In Sura 11: 118 "If thy Lord willed, He would have made man of one people, but they were always at loggerheads.

\section{Guarantee of Salvation for Those who believe in Allah and Final Day.}

As the majority religion in Indonesia, according to Zahlani Zain [32], Islam should be the decisive parameter of the creation of the continuity of harmonious majority-minority relations, especially in providing protection to minorities, religious or ethnic minorities. In this case Islam is faced with opportunities and challenges that are quite heavy in the context of the plural society of Indonesia. The challenge to what extent Islam can pioneer the building of harmonious and nondiscriminatory relations. Allah guarantees salvation and a final life is good for those who want to believe in God and the last day. This assurance appears not only promised to Muslims, but also the early peoples. Surah 2: 62 "Surely the believers, the Jews, the Christians, and the Sabians, any of them who truly believe in Allah, the Last Day and do good deeds, they will receive the reward of Their Lord, there is no fear for them, neither shall they grieve. This is a guarantee specifically promised by God. In a similar vein is also implied in the letter 5:69 "Surely the believers, the Jews, the Shabbatites and the Christians, anyone (among them) who truly believe in Allah, the day after and do good deeds, there is no fear of them, neither shall they grieve; 2:82 And as for those who believe and do righteous deeds, they are the inhabitants of heaven; they are eternal in it. It also appears in Surah 2: 121 "Those whom We have given the Book to them, they read it with true reading, they believe in it. And whoso breaketh unto him, they are the losers. And also in Surah 2: 218 "Verily those who believe, those who emigrate and strive in the Way of Allah, expect the mercy of Allah, and Allah is Forgiving, Most Merciful. Inserted in Sura 2: 277 "Surely those who believe, do good deeds, establish shalat and pay zakat, they are rewarded by their Lord. There is no fear for them nor do they grieve.

\section{Various Prophets but One People}

God sent messengers and prophets to mediate God's message to man. God sent the Prophet as a merciful giver. In Sura 2: 213 "Man is one people. (After a dispute arose), God sent the prophets to be glad tidings and warners, and Allah sent them down with the Books correctly, to make decisions among men about the matter in which they disputed. There is no dispute concerning the Book but the one who was sent to them the Book, that is, after coming to them the real testimonies, out of envy among themselves. So Allah gives guidance to those who believe in the truth about what they disputed with His will. And God always gives guidance. In other letters are also firmly called, for example, letters 10:19 "People formerly only one people, then they disagree. Had it not been for an existing provision of your Lord, it must have been given a decision among them, of what they were disputing. Though easy for God. Sura 11: 118 "If thy Lord willed, He would have made man of one people, but they were always at loggerheads. The same appeal appears in 16:93 "And if God wills He will make you a people, but Allah deceives whom He will, and guides whom He will. And verily you shall be asked of what you have done. But of the many prophets who are sent in general carry the message tauhid. In Sura 21: 92 "Truly (this religion of monotheism) is the religion of all of you; one religion and I am your Lord, so worship Me. 23: 53 Then they (the followers of the apostle) made their religion divided into several fractions. Each group feels proud of what is on their side (each).

\section{E. There is No Coercion in Religion}

Islam is a clear religion. The Qur'an describes as an option that must be based on willingness and sincerity. There is no compulsion and give space to choose. Because good and evil are all clear. In Sura 2: 256 "There is no compulsion for (enter) religion (Islam); in fact it is clearly the right path rather than a misguided path. Therefore whoever disbelieves in Thaghut and believes in Allah, then surely he has clung to a very strong rope that will never break. And Allah is Hearing, Knower. And it also appears in Sura 3: 85 "Whoever seeks a religion other than Islam, then will not be accepted (the religion) from him, and he in the Hereafter including the losers; 3:83 Do they then seek other religions from the religion of Allah, when to Him who 
submit to all that is in the heavens and the earth, whether with pleasure or compulsion, and only to Allah are they returned? 109: 6 for your religion and for me my religion. "The choice and the right of choice are entirely left to humans, Whether faith or not is an option But only fools do not choose the way of faith In Sura 2: 130" And no one hates religion Ibrahim, but the one who fools himself, and indeed We have chosen him in the world and indeed he in the Hereafter truly belongs to the righteous.

\section{$F$. Be religious with love}

Islam as rahmatan lil alamin teaches its people to always behave spreading affection. In 8:22 "You will not find any people who believe in Allah and the Last Day, are affectionate with those who oppose Allah and His Messenger, even if they are fathers, or children or siblings or their families. Those are the people whom God has planted faith in their hearts and strengthened them with help that came from Him. And He put them into Paradise flowing beneath which rivers flow, they will abide therein. God is pleased with them and they are content with His (grace). They are the people of God. Behold, that is Allah's class which is the lucky one. The lucky one is the one who believes and counsels each other in patience and piety. In Sura 90:17 "And he is among those who believe and exhort each other to be patient and exhort each other to be merciful. Love and gentleness are the greatest graces of God to man. In Sura 3: 159 "It is by the grace of God that you are gentle with them. If you were to be tough again, they would have distanced themselves from your surroundings. Therefore forgive them, ask forgiveness for them, and consult them in that matter. Then when you have started.

The development of Islam in PTKIN is based on the belief that the difference is the main gater for mutual learning. Mentioned in Quran as yaayyuhannas inna khalaknakum min dzakarin wa unsa ... lita'arrafu. Humans have many identities, both related to race, religion, class, and social status. These identities are something given, and some are sociological constructs. Therefore, according to Budi Munawar Rahman [33] that pluralism as a social reality. Diversity as a sign of God's greatness for his people to want to think. As Mentioned Quran wa min ātihi khalqa as-samâwât wal alrdh wakhtilâf al sinatikum wa alwânikum. Diversity is just a test of what comes to humanity [34].

Uniformity is frost, even called prophet will lead to destruction, because uniformity contains statism, counterproductive and enemies of dynamism As He Said lâ yazal annâs fi khair mâ tabayyanû wa in tasawwû halaqû. Islam is now looking at humanitarian areas, as a matter of concern to avoid conflicts in the name of religion. 'Religion for peace' or 'min al iman ila al ukhuwwah' as a theme that can be offered to build understanding and understanding between religions and beliefs, to build a brotherhood of humanity (ukhuwah insaniyah), interreligious harmony and brotherhood as nationals duty. This dialogue will give rise to "interfaith understanding," if an understanding of multiculturalism, diversity and inclusiveness become common consciousness: Humans have different heads, different contents, different understandings, different thoughts and options. Excellence and limitations must be respected. Or lack thereof, but positive things are more important to discuss together to synergize to build life. Create Dialogue of Understanding and Dialogue of action.

Therefore, building that understanding becomes important, some of PTKIN's allegations receive diversity among others; First, Differences must be regarded as the mercy of God, and it is not permitted for anyone to intimidate, coercion on the grounds of difference. Second, restoring all judgments of faith, ideology and belief to each other's conscience and avoiding truth claims over religious interpretations. Truth let be the authority of God, and respect the choice of beliefs of others. Third, Respect human life as a person who equally has the right to live, develop, work and make choices of beliefs according to his conscience. Fourth, diversity is a sign of God's greatness for human beings to learn from each other, understand and complement each other. [34].

Some PTKIN pioneered interfaith cooperation to affirm the vision of nationhood. For PTKIN, Religious Dialogue is a means of eliminating even more suspicion than that, discussing the social problems facing the nation today. Within the PTKIN the interfaith dialogue in the past year has already begun to spread the theme, not only dialogue on theology, sharing of religious experience, but developing in response to real issues facing religious people in life. The most recent issues that are being lifted are; [1] social and economic injustices resulting from modemization and globalization which only a few groups enjoy, while others are exploited and marginalized. [2] The bias of the mass media as a center for information dissemination is sometimes trapped in less productive provocations and prejudices. [3] an environmental and ecological crises [4] poverty [5] child exploitation and violence in women and [6] community demoralization and corruption.

PTKIN dismisses violence by developing a spirit of openness. De radicalization can begin by opening up to differences. Even dare to acknowledge the existence of others. While there is suspicion and fear will trigger tension. In the tensions and challenges of horizontal conflict today all parties can be wise with; [1] Ensuring freedom of religion, which is essential to meet religious needs in plural society in Indonesia. [2] Promote mutual respect, appreciation and cooperation among different religious groups, to support local, regional and national stability as a prerequisite for development and [3] facilitate institutionally as a center for interreligious religious studies.

PTKIN thus carries an important mandate in the dynamics of this change, which is to become a carriage and strategic institutions to prepare Muslims who have a strong commitment to be strong, have the ability to adapt to a pluralistic society and can be democratic. El Hassan bin Talal, and Alain Elkann in To Be a Muslim: Islam, Peace, and Democracy [35] refers to being a good Muslim, peace loving and adaptable and democratic

\section{CONCLUSION}

Islam is a flexible religion that can be understood and translated from different perspectives. But still must rely on the principles of Tawheed and morals karimah. In today's global age, Islam is faced with a crucial global challenge. There is a special strategy to communicate Islam's awareness and develop 
an Islamic dialogue creatively with globalization. It will be the foundation for building a multi-cultural, multi-ethnic society. The encounter of Islam and globalism ultimately become a progressive force to support development. Instead, it becomes a trigger to break the unity and cohesiveness of people. Here it becomes interesting how to formulate and understand Islam that is in line with the inevitable social change. The development of Islam in PTKIN is based on the belief that Difference is the main door to mutuality. Humans have many identities, both related to race, religion, class, and social status. These identities are something given, and some are sociological constructs.

PTKIN has a strong institutional foundation for developing universal, normative and descriptive Islam and continuously developing interreligious dialogue. In the last year has expanded its theme, not just only dialogue on theology, sharing of religious experiences but also developing on the response of real problems faced by religious people life. Issues of social and economic injustices resulted from modernization and globalization, media bias, peace building dissemination, prejudices climate, environmental and ecological crises, poverty, child exploitation and violence to women and demoralization of society and corruption.

In the tensions and challenges of horizontal conflict today PTKIN promotes invitations to tolerance and invites all parties to be wise by providing a space for religious freedom, which is essential to meet religious needs in plural society in Indonesia. Promote mutual respect, appreciation and cooperation among religious groups, to support local, regional and national stability as a prerequisite for development and the most strategic facilitation institutionally as a center for universal Islamic studies and a center for the promotion of interreligious relations.

\section{REFERENCES}

[1] Jalaluddin Rahmat, Islam Aktual, Refleksi Sosial Seorang Cendekiawan Muslim, Bandung, Mizan, 1991.

[2] Azumardi Azra, Islam Substantif, Agar Umat Tidak Jadi Buih, Idris Thaha, Editor, Bandung, Mizan, 2000

[3] Moh. Sulhan, Kontestasi Tafsir Agama, Konflik Agama dan Problem Pluralisme, Kuningan, Crisis Press, 2013

[4] Mark R Woodward, Indonesia, Islam dan Orientalisme: Sebuah Wacana yang Melintas dalam Taufik Abdullah, Dkk, Jalan Baru Islam Memetakan Paradigma Mutakhir Islam Indonesia, Mark R Woodward, Editor], Bandung, Mizan, 1998.

[5] Syamsu-1 Arifyn Munawwir, Islam Indonesia di Mata Santri. Pasuruan: Pustaka Sidogiri, 2013

[6] Rubaidi, A. Radikalisme Islam, Nahdlatul Ulama; Masa Depan Moderatisme Islam di Indonesia. Yogyakarta: Logung Pustaka, 2010

[7] Kamarudin Amin Dkk., Editor, Quo Vadis Islamic Studies In Indonesia Current Trends and Future Challenges, Jakrta, Diktis, UIN Alaudin Makasar, 2006

[8] Musahadi, Islam Sebagai Sasaran Studi, Identifikasi Awal terhadap Problem, Pola dan Pendekatan Studi Islam di Indonesia, dalam Kamarudin Amin Dkk., Editor, Quo Vadis Islamic Studies In Indonesia Current Trends and Future Challenges, Jakrta, Diktis, UIN Alaudin Makasar, 2006
[9] Abdul Djamil, Studi Islam Indonesia dalam Tradisi Kesarjanaan Belanda dalam Sudar Noto Abdul Hakim, Penyunting, Islam Berbagai Perspektif, Yogyakarta, LPMI, 1995

[10] Jhon Esposito, Ancaman Islam Mitos Atau Realita, Bandung, Mizan 2001

[11] John R. Bowen, Muslims Through Discourse, Princenton, Princenton University press, 1993.

[12] Jhon O Volt, Islam, Change and Continuity in the World, Bolder: Colo Westview, Press, 1982.

[13] Zainuddin Fananie dkk. Radikalisme Keagamaan dan Perubahan Sosial, Surakarta, Muhammadiyah University Press, 2002

[14] Very Verdiansyah, Islam Emansiatoris Menafsir Agama Untuk Praksis Pembebasan, Jakarta, P3M, 2004

[15] Abdurrahman Wahid, Dkk. Islam Tanpa Kekerasan [ Glen D Paige, Editor, Yogyakarta, LKIS, 2000.

[16] Greg Fealy, Greg Barton, Editor,Tradisionalisme Radikal Persinggungan NU dan Negara, Yogyakarta, LKIS, 1997.

[17] Fawaid Sadjili, Temu Tengkar Agama dan Tradisi Lokal, Tashwirul Afkar, Edisi No 23 tahun 2007.

[18] Ronald Alan Lukens-Bull, Jihad Pesantren di Mata Antropolog Amerika, Yogyakarta, Gala Media, 2004.

[19] Sahal Mahfudh, Epistemologi Fiqh Sosial, Konsep Hukum Islam dan Pemberdayaan Masyarakat, Pati, STAIMAFA, 2013.

[20] Ahmad Baso. Islam Pasca Kolonial Perselingkuhan Agama, Kolonialisme dan Lieralisme, Bandung, Mizan, 2005

[21] Syafii Maarif, Membumikan Islam, Yogyakarta, Pustaka Pelajar, 1994.

[22] Moh. Abid al Jabiri, Agama, Negara, dan Penerapan Syariah, Yogyakarta,, Fajar Pustaka Media, 2001.

[23] Sayyid Hosein Nasr, Traditional Islam in The Modern Word, New York, Newyork University Press, 2001

[24] Syafi'I Ma'arif, Intelektualisme Islam, Bandung, Mizan, 2000.

[25] Wildan Taufiq, Semiotika untuk Kajian Sastra dan Alquran, Bandung, Yatra Media, 2016.

[26] Roger Boase [Editor], Interfaith Islam And Global Dialogue: Religious Pluralism And The Pursuit Of Peace Foreword By Hassan Bin Talal [Ashgate Publishing, 330pp., 2005]

[27] Moh Sulhan, "Kekerasan", Toleransi dan Inklusivisme”, (Mitra Dialog 29 Nopember 2004).

[28] Komaruddin Hidayat, Mitologi dan Radikalisme Agama, Kompas, 13$12-2002$

[29] Mochtar Buchari, Radikalisme Keagamaan, Perubahan Sosial dan Kewaspadaan Masyarakat, Sebuah Catatan, Jakarta, LIPI, 2002.

[30] Abu Hafsin,, Dkk, Urgensi Regulasi Penyelesaian Konflik Umat Beragama: Perspektif Tokoh Lintas Agama, Jurnal Walisongo, Volume 22, Nomor 2, November 2014

[31] Mohammed Abu-Nimer, Peace And Conflict Resolution, Nonviolence and Peace Building in Islam: Theory and Practice, Gainesville, FL: University Press of Florida, 2003. ix +186 pages. Notes to p. 211. Index top. 233. $\$ 55$.

[32] Zahlawi Zain, "Perlindungan Hak-hak Minoritas" dalam Buletin AnNadzar, Edisi 32/14 Nopember 2003, h.1G. Eason, B. Noble, and I.N. Sneddon, "On certain integrals of Lipschitz-Hankel type involving products of Bessel functions," Phil. Trans. Roy. Soc. London, vol. A247, pp. 529-551, April 1955. (references).

[33] Budhy Munawwar Rahman, Islam dan Pluralisme Nurcholish Madjid, Pusat Studi Islam dan Negara Universitas Paramadina, 2007

[34] Moh. Sulhan, Islam Realitas Agama, Perubahan Sosial dan Kompleksitas, Kuningan, Crisis Press, 2015

[35] El Hassan bin Talal, and Alain Elkann. To Be a Muslim: Islam, Peace, and Democracy. Sussex Academic. 2004. c.96p. ISBN 1-903900-81-6. \$35; pap. ISBN 1-902900-82-4. \$17.95. REL 